\title{
Indexing Adequacy and Interdisciplinary Journals: The Case of Women's Studies
}

\section{Kristin H. Gerhard, Trudi E. Jacobson, and Susan G. Williamson}

\begin{abstract}
This paper examines access to women's studies journals through standard indexes and abstracts. Reliability of coverage is important for women's studies scholars and possibly other young interdisciplines. Articles from eighty-six journals were searched in online and print indexes. Access to each journal was evaluated as adequate or inadequate based on fixed criteria. Over 60 percent of the journals were inadequately indexed. These titles should be added to appropriate indexes; a list of specific recommendations is appended (see Appendix A). Parallel research in similar fields may allow librarians to draw generalizations about access to interdisciplinary materials.
\end{abstract}

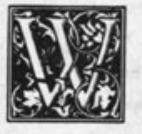

omen's studies programs have been present in American universities for more than twenty years. A number of core bibliographies have been developed for the discipline (or interdiscipline) and list serial titles covering a wide subject range. The accessibility of material covered in these serial titles is important for current researchers in women's studies. This paper examines access to women's studies serials through standard indexing services typically found in larger research libraries.

The authors' interest in examining the coverage provided by these sources comes from the desire to be fairly certain that the major articles in journals used regularly by women's studies scholars are being indexed in sources available in

Kristin H. Gerhard is Catalog Librarian, Iowa State University, Ames, Iowa 50011-2140; Trudi E. Jacobson is Bibliographic Instruction Coordinator, University at Albany, State University of New York, Albany, New York 12222; and Susan G. Williamson is Head Librarian, Annenberg School for Communication, Philadelphia, Pennsylvania 19104.

The data on which this study is based were collected by nine librarians. They are: Ruth Dickstein, University of Arizona; Kristin H. Gerhard, Iowa State University; Carol Greenholz, College of Technology, State University of New York; Judith Hudson, University at Albany, State University of New York; Mary Ellen Huls, College of St. Catherine; Trudi E. Jacobson, University at Albany, State University of New York; Bernice Lacks, California State University, Fresno; Rita M. Pellen, Florida Atlantic University; and Beth Stafford, University of Illinois. The discussions that took place as the data were collected and assembled contributed greatly to the preparation of this article. The authors wish to thank Judith Hudson, in particular, for her work as the leader of the project. A study leave granted by the Joint NYS/UUP Professional Development and Quality of Work Life Committee allowed her to organize and analyze the data which form the heart of this study.

The research carried out in this project was assisted greatly by grants from BRS, Dialog and the $H$. W. Wilson Company. Each of the aforementioned companies provided access to their online services at no charge to the researchers. 
large academic libraries. If this is not the case, which indexes can be relied upon to provide broad and thorough coverage? Which provide narrower coverage? Are some indexes more or less dependable than others? This information is crucial to researchers in women's studies and to those who advise them.

Reliable coverage is also important for those not directly involved in women's studies. Because women's studies is an interdiscipline, studies appearing in women's studies journals often have applications in other disciplines. These studies should be accessible to scholars not necessarily looking for research from a women's studies perspective.

Another reason for adequate coverage is that many libraries weigh such coverage heavily in selection decisions. Susan E. Searing and Joan Ariel point out:

One typical criterion for adding new periodical titles is the availability of indexing. If a periodical is covered by an index or abstract heavily used by library patrons, one can predict a corresponding demand for the periodical. . . . Regrettably, standard indexes continue to ignore many serials essential to women's studies.... 1

In a time of shrinking serials budgets and rising serials prices, titles not included in indexes may be particularly vulnerable to cuts.

The review of the literature that follows examines women's studies as an interdiscipline, theavailability of specialized index sources for women's studies, and previous research related to coverage of women's studies journals.

\section{WOMEN'S STUDIES AS AN INTERDISCIPLINE}

Interdisciplinary areas such as women's studies are, by their nature, difficult areas in which to conduct research. Information relevant to any given project is spread among multiple disciplines rather than concentrated in one area of the stacks, one index, or one range of the reference collection. The dispersed nature of relevant information and the amount of time and effort involved in identifying useful articles make index coverage of journals in interdisciplinary fields especially important. Online indexes, in particular, have the potential to save researchers valuable time if those indexes cover the journals likely to contain material of interest to researchers in a given interdiscipline.

\section{INDEXES FOR WOMEN'S STUDIES}

Helen B. Josephine and Deborah K. Blouin examined reference sources on women, evaluating some existing sources and identifying gaps where additional sources were needed. Types of sources they identified as lacking for women's studies included "statistical sources, encyclopedias, yearbooks, and abstracting and indexing sources including databases." They continue: "This is certainly not an exhaustive list of sources that need to be published in women's studies. However, the lack of adequate sources in these four areas has hampered research and frustrated librarians for years." 2

Currently, three interdisciplinary women's studies indexes are available: Women's Studies Index, Women Studies Abstracts, and Studies on Women Abstracts. Aside from the confusing similarity of names, they share one major drawback: none is available online. However, these are the only basic indexes one can use to search for materials related to women that are published in more than one subject area.

The now defunct Catalyst database is the subject of several articles. This database was available through BRS and Dialog until June 1988. It provided access to the Catalyst Library's holdings, which relate to women and work. Although available online, it covered only a narrow band of the spectrum of materials on women. Another online source, Sociological Abstracts, allows searches of a subset, Feminist/Gender Studies (area 29). Still, there is no single online index that broadly covers women's studies journals across disciplines.

Without such an index, the coverage provided in bits and pieces by the more discipline-oriented indexing services takes on particular importance. Josephine and Blouin point out that, because of the lack 
of a single, universal database on women, "searching the indexes, abstracts and online sources relevant to women's studies requires sophistication and persistence." ${ }^{\prime 3}$ As Helen Rippier Wheeler comments, "In research, as in the rest of life, feminist researchers must expect to make do with that which is available to them and to pioneer."4

\section{PREVIOUS RESEARCH ON COVERAGE}

In 1984, Mary Alice Sanguinetti documented increasing coverage of women's studies in indexes from 1972 to 1982 . She identified a core list of fifty-three women's studies periodicals. Only about half were indexed at that time. More than a quarter were indexed by at least four services. "Eight indexing and abstracting services ... each cover[ed] five or more of the titles." ${ }^{\prime 5}$ While one would anticipate the numbers to be better ten years later, Sanguinetti's conclusions are still relevant:

Librarians and researchers in women's studies will probably need to continue referring to several indexes for needed material. An awareness of where the most relevant periodicals are indexed should prove beneficial to these as well as to others with an interest in women's studies. ${ }^{6}$

Sanguinetti does not address the question of how she determined which journals were indexed by a given service, but the implication of her article is that she worked with lists supplied by the indexes themselves. One of the questions that arose during this study is the reliability of such lists.

Suzanne Hildenbrand looked at end user satisfaction of those searching online for topics in women's studies. She found that researchers' evaluation of search results was related to the number of raw citations retrieved and the percentage of citations the researchers perceived to be relevant.' Improved coverage would likely lead to retrieval of more relevant references in these searches. One can conjecture that user satisfaction would be increased by increasing the breadth and depth of coverage of relevant journals in women's studies.
In another report on the same study, Hildenbrand says:

Coverage problems were evident in the study but do not lend themselves to extended discussion. The wise searcher must simply note the gaps in discipline, publication format, and retrospective coverage and consider what substitutions, if any, can be made. ... ${ }^{8}$

She considered coverage of journals to be "generally good." Hildenbrand also noted that librarians "have a role in the promotion of improvements in the indexing, quality, and coverage of databases available for WS research." ${ }^{\prime 9}$ In order to promote such improvements, librarians must first develop a clear picture of the existing coverage of women's studies journals, based on a systematic exploration of that coverage. That is the main purpose of this study.

\section{METHODOLOGY}

The goal of this project was to analyze indexing coverage of women's studies articles for the year 1988. Data collection was performed by a group of nine librarians. The methodology was essentially a literature search in reverse: searchers began with journal articles and then sought indexes containing citations to those articles.

Eighty-six journals were analyzed. The initial set of journals was identified by searching the sixth edition of Katz and Sternberg's Magazines for Libraries. It included all current titles listed under the following headings: Women'sStudiesGeneral; Women-Feminist; Women - Literary and Artistic; Lesbian and Gay; and Afro-American.

This list of journals was distributed to the nine participating librarians. Additional recommendations for inclusion were also sought. The result was an initial working list containing 120 titles. Once this working list was established, each journal was searched on OCLC and $R L I N$ to determine whether it was still being published and which libraries held it. The bulk of the list was divided up and assigned to individual searchers, based on access to the titles and subject 
expertise. The remaining titles were allotted arbitrarily to searchers to even out assignments.

As data collection began, it became clear that not all titles on the list were appropriate to this study. The group agreed to exclude certain types of material from the search process. This resulted in the final list of eighty-six journals. The group also devised strategies for dealing with differences of journal type (e.g., journals consisting of book reviews versus articles). The following guidelines were used:

- Newsletters, such as NOW Times or Media Report to Women, were excluded from the search because of their inherently ephemeral nature, the likelihood that they would not be indexed, and the fact that, though these materials cover important issues, they do not do so in depth.

- Journals consisting primarily of fiction, poetry, and drama were dropped from the list. This decision was not made to suggest that these literary genres are unworthy of indexing or of analysis; rather they constitute a very different category of women's studies materials that should be analyzed in a separate study.

- Journals which ceased publication during or since 1988, such as Helicon Nine, were excluded.

- In addition to articles, book reviews in journals were analyzed. In cases where a journal was devoted entirely to book reviews (such as Women's Review of Books), a maximum of twenty-five reviews from each issue was analyzed.

- Although the project coverage was restricted to the year 1988, it was occasionally necessary to analyze issues from the preceding year, if a journal had been issued less than twice a year or if it was impossible to obtain all the 1988 issues. When a journal was issued more than six times a year, the searcher was asked to select six issues from 1988 to analyze. This established a minimum and maximum number of issues to be examined for each journal.

- Only articles of substance were considered appropriate for analysis. In many cases, the decision to analyze was a judgment call based primarily on length and, in some cases, subject matter of the article.

In looking for index citations, some searchers began with the tables of contents for all 1988 issues for their chosen set of journal titles; others transcribed the titles onto a work sheet and arranged the articles on it alphabetically by author. Searchers then chose indexes appropriate to the subject matter to search, working from a checklist. Some members of the group used Ulrich's indexing information to provide a starting point for the search. They discovered that the information in Ulrich's was not always reliably current; some of the journals said to be indexed by particular indexing sources had been dropped. If a searcher found that a journal title did not appear in an index's printed list of journals included in that index, they recorded coverage as zero. If the title did appear, the searcher analyzed the index for the number of articles, reviews, and so forth actually included, recording the number and percentage of items covered. Each search for citations began with known items (author, title) and followed with subject or keyword searching when the known items produced no hits.

Where possible, searchers conducted an online search. At their disposal were hours of free searching provided by $B R S$, Dialog, and Wilson. When indexes that might be appropriate were not available in a group member's library, the titles and tables of contents were sent to other searchers to check against their index holdings and report the results. The number of indexes checked varied according to subject area, ranging from eleven for the more narrow categories of law and lesbian journals, to forty-one and forty-three for the broader categories of the humanities and social sciences.

If no indexes provided coverage for a journal title or if the journal was only meagerly covered in indexes, searchers were asked to recommend names of indexes that might be appropriate for inclusion. Each individual based his or her recommendations on a set of criteria 
TABLE 1

WOMEN'S STUDIES JOURNALS IN THE HUMANITIES

\begin{tabular}{ll}
\hline *Anima & *Iris \\
*Atlantis & * Journal of Feminist Studies in Religion \\
* Belles Lettres & * Journal of Women \& Religion \\
Camera Obscura & Legacy \\
$*$ Creative Woman & Lilith \\
${ }^{*}$ Daughters of Sarah & Tulsa Studies in Women's Literature \\
Gallerie & * Women \& Language \\
${ }^{*}$ Genders & * Women and Performance \\
${ }^{*}$ Heresies & Women's Art Journal \\
Hot Wire & $*$ Women's Studies in Communication \\
Hypatia & *Zora Neale Hurston Forum \\
\hline
\end{tabular}

* Titles marked with an asterisk are not adequately indexed.

for indexing adequacy agreed upon by members of the group. The criteria were as follows:

- Important women's studies titles should be indexed in at least one of the three interdisciplinary women's studies indexes.

- Titles belonging to a specific field or discipline should be indexed in at least one key index for that discipline.

- Interdisciplinary women's studies journals respected for scholarly content should be indexed in a broad interdisciplinary index such as Social Sciences Index or Humanities Index.

- Periodicals or magazines not directed to an academic audience should be indexed when appropriate in a general index such as Reader's Guide or Magazine Index.

The results of the search process and the list of recommendations were placed in a matrix arranged by journal title and index or abstract. A spreadsheet was used to house the matrix and to generate two lists: one with titles not requiring further indexing, and the other with titles requiring further indexing, arranged by index.

\section{RESULTS}

The analysis that follows examines the results of the study in two ways: by journals in broad subject areas, and generally, by index or abstract. The questions considered include: Are individual journals indexed sufficiently? Which ones are not, and where might they be indexed? Which indexes are doing a good job of covering women's studies journals? Which ones might reasonably be expected to cover additional journals?

The methodology was essentially a literature search in reverse: searchers began with journal articles and then sought indexes containing citations to those articles.

The journals the authors examined fall into six broad subject areas: humanities, law, lesbian studies, social science, women's studies, and the catch-all "other." Of eighty-six titles, twenty-two were in the humanities. As shown in table 1, eight of these journals are adequately indexed: Camera Obscura, Gallerie, Hot Wire, Hypatia, Legacy, Lilith, Tulsa Studies in Women's Literature, and Woman's Art Journal. One journal, Zora Neale Hurston Forum, was not indexed at all. The remaining thirteen journals were indexed, but not fully or not in all the pertinent indexes.

Six law journals were included in this study (see table 2). Those adequately indexed were Berkeley Women's Law Journal, Canadian Journal of Women 
TABLE 2

WOMEN'S STUDIES JOURNALS IN LAW

Berkeley Women's Law Journal

Canadian Journal of Women and the Law

* Harvard Women's Law Journal

${ }^{*}$ Law \& Inequality

Wisconsin Women's Law Journal

Women's Rights Law Reporter

* Titles marked with an asterisk are not adequately indexed.

\section{TABLE 3}

WOMEN'S STUDIES JOURNALS SPECIFIC TO LESBIAN STUDIES

* Bad Attitude

* Breaking the Silence

* Lesbian Contradiction

* Lesbian Ethics

*Sinister Wisdom

*Visibilities

* Titles marked with an asterisk are not adequately indexed.

and the Law, Wisconsin Women's Law Journal, and Women's Rights Law Reporter. Harvard Women's Law Journal and Law \& Inequality were not adequately indexed. Harvard Women's Law Journal should be picked up by a women's studies tool, perhaps Women Studies Abstracts. Law \& Inequality should be included in both women's studies and other indexes.

Of the six lesbian journals, only one, Lesbian Contradiction, was indexed at all, and by just one index, Alternative Press Index. The remaining five were not included in any indexes or abstracts (see table 3). Most should be included in women's studies indexes, and the authors also recommend that Alternative Press Index include two more of these journals.

Indeed, it is not simply the lack of indexes and abstracts that include women's studies journals that is so frustrating-it is also the unpredictable nature of the women's studies journal indexing that is done in most indexes and abstracts.

The indexing of eighteen social sciences journals (see table 4) was examined, and, as with indexing of journals in other categories, was generally found to be inadequate for researchers attempting to find these articles by topic. Seven of the eighteen were indexed well. They were Peace and Freedom, Psychology of Women Quarterly, RFR, Sage, Sex Roles, Women and Environments, and Women \& Therapy. Male/Female Roles was not included in any index or abstract; because it contains only very brief articles, this was considered appro-

TABLE 4

WOMEN'S STUDIES JOURNALS IN THE SOCIAL SCIENCES

* Ahfad Journal

* Feminist Teacher

* Gender \& Society

* Hecate

Male/Female Roles

*Manushi

* Minerva

* Mothering

Peace and Freedom
Psychology of Women Quarterly

RFR

Sage

Sex Roles

* Studies in Sexual Politics

* Woman of Power

Women and Environment

* Women \& Politics

Women and Therapy

* Titles marked with an asterisk are not adequately indexed. 
TABLE 5

WOMEN'S STUDIES JOURNALS SPECIFIC TO WOMEN'S STUDIES

\section{* Australian Feminist Studies \\ Broadsheet}

Broomstick

Canadian Women's Studies

${ }^{*}$ Feminisms

* Feminist Collections

* Feminist Bookstore News

Feminist Issues

* Feminist Review

${ }^{*}$ Feminist Studies

* Fontiers
*NWSA Journal

* New Directions for Women

Signs

* Sojourner

* Spare Rib

* Trivia

* Trouble and Strife

Women's Review of Books

Women's Studies

* Women's Studies International Forum

Women's Studies Quarterly

* Titles marked with an asterisk are not adequately indexed.

priate. Mothering was similarly not included in any index or abstract even though it has significant content. The remaining journals should be more fully indexed than they currently are.

Twenty-two journals the authors examined were grouped into the women's studies category (see table 5). Eight of these journals were well served by indexes. They were Broadsheet, Broomstick, Canadian Woman Studies, Feminist Issues, Signs, Women's Review of Books, Women's Studies, and Women's Studies Quarterly. Three journals did not receive any coverage: Feminisms, Feminist Bookstore News, and Sojourner. Accessibility of the material in most of the remaining eleven journals would profit from indexing beyond what is currently being done.

The "other" category was made up of twelve journals, ranging from Executive Female to Hurricane Alice, from Reproductive and Genetic Engineering (now Issues in Reproductive and Genetic Engineering) to Women's Sports and Fitness (see table 6). Four of the twelve, Affilia, Executive Female, Healthsharing, and Women \& Health, were sufficiently indexed. Hurricane Alice, Tradeswoman, and WLW Journal were not indexed by any of the numerous indexes and abstracts that the authors checked. Because it contains primarily personal essays, memoirs, and reviews, the authors considered the lack of indexing for Hurricane Alice rea- sonable. The remaining five journals were insufficiently covered.

Because of the large number of indexing tools examined, a report on which indexes include which journals is not practical. A chart of the journals and the indexes in which they were found are available from the authors. Sanguinetti's "Indexing of Feminist Periodicals" includes a similar report. Her report covers a smaller number of services than those included in this study.

A number of indexes and abstracts should extend their coverage of the women's studies literature to enable

TABLE 6

OTHER WOMEN'S STUDIES JOURNALS

\section{Affilia}

Executive Female

* Health Care for Women International

Healthsharing

Hurricane Alice

* Lambda Rising Book Report

* On the Issues

* Reproductive/Genetic Engineering

* Tradeswoman

* WLW Journal

Women and Health

* Women's Sports and Fitness

* Titles marked with an asterisk are not adequately indexed. 
researchers to find this material more easily. A list is appended of indexing tools and the women's studies titles they could reasonably be expected to add based upon their audience and scope (see Appendix A). The authors recommend that many of the indexes and abstracts pick up just one or a few additional titles. However, the authors also recommend that Alternative Press Index, General Periodicals Index (Academic Version), Humanities Index, MLA Bibliography, and Social Sciences Index add five or more women's studies titles. These are widely used indexes and abstracts with the potential for broad impact on the accessibility of women's studies literature.

To avoid duplication, the authors' guideline is to suggest that scholarly journals not yet covered by a women's studies index be added to Women Studies Abstracts, and that more general women's studies journals be added to Women's Studies Index.

Indexes specific to women's studies could also be strengthened. To avoid duplication, the authors' guideline is to suggest that scholarly journals not yet covered by a women's studies index be added to Women Studies Abstracts, and that more general women's studies journals be added to Women's Studies Index.

Accordingly, the authors recommend that Women Studies Abstracts add eight titles. This abstract is already an essential tool for doing women's studies research. Many researchers rely upon it heavily, expecting it to be inclusive. The addition of these journals would help the abstract merit the reputation it already has. One of these eight journals, Lesbian Ethics, is not currently indexed anywhere else, while the remainder would logically be included here as well as elsewhere. Women's Studies Index, the new G.K. Hall tool, should pick up another nine titles, three of which are not currently indexed. The authors recommend that Studies on Women Abstracts add three titles, and more fully index another three.

\section{CONCLUSIONS}

The overall finding of this study is that most women's studies journals, fifty-three out of eighty-six, are not sufficiently indexed. While several indexes and abstracts (notably Alternative Press Index, Women Studies Abstracts and Women's Studies Index) are doing a commendable job in this regard, other indexes and abstracts are ignoring relevant journals or are only picking up a small percentage of articles within a given journal. Indeed, it is not simply the lack of indexes and abstracts that include women's studies journals that is so frustrating - it is also the unpredictable nature of the women's studies journal indexing that is done in most indexes and abstracts. For example, American Humanities Index indexed five out of twelve articles from the fall 1988 issue of Anima, but indexed none from the spring 1988 issue. Occasionally, an index indicates that it covers a particular journal (for example, Studies on Women Abstracts in regard to Atlantis), yet no citations to articles from the journal could be found during the year examined. So the issue is not simply that more women's studies journals need to be indexed, but also that they need to be indexed more consistently. Reliability of indexing is particularly important in preventing researchers from believing that they have identified all relevant materials when, in fact, they have not.

Lesbian journals seem to have been given particularly short shrift in the indexes the authors searched; they were the least-indexed category, despite the growth of lesbian studies in recent years.

This study did not examine coverage of several important kinds of women's studies materials: media reviews, literature, or coverage of newsletters in news indexes. These are potential areas for future study. Also, the authors did not explicitly set out to evaluate the quality of the lists provided by indexing and abstracting services that give the titles they intend to cover. While the authors have noted some serious inconsistencies, the authors think this situation could be remedied if all indexes listed the specific journal issues the indexes have included, 
and if indexes would adopt, as a professional standard, the practice of delineating their indexing policy (how comprehensively do they index, which types of articles, which not, who decides and on what basis) in their printed materials. Some services already provide part or all of this information. Those which do not should give it serious consideration.

The study also shows a need for a comprehensive online index for women's studies. The availability of an indexing or abstracting service specific to women's studies, online or on CD-ROM, would go a long way to enhance the ease with which women's studies scholars carry out their research.

The patterns of indexing discovered in this study may be similar to those of other emerging or young interdisciplinary fields. It would be valuable to com- pare indexing patterns in women's studies with those for fields such as sociobiology, black studies, peace stud-ies, or aerospace studies. Is indexing coverage similar? Do researchers in these fields have online indexing ser-vices available to meet their needs?

The task facing an interdisciplinary researcher, that of gathering together the scattered information related to a topic, can be a formidable one. Improving index access to interdisciplinary materials is one way to reduce this burden to a manageable size. There is always the risk with interdisciplinary areas that access to some portion of their resources will fall between the cracks. It is only by examining the indexing of materials related to an area, such as women's studies, that access can be evaluated and appropriate improvements suggested.

\section{REFERENCES}

1. Susan E. Searing and Joan Ariel, "Women's Studies," in Selection of Library Materials in Applied and Interdisciplinary Fields, ed. Beth J. Shapiro and John Whaley (Chicago: Collection Management and Development Committee, Resources and Technical Services Division, American Library Assn., 1987), 261.

2. Helen B. Josephine and Deborah K. Blouin, "New Reference Sources on Women: An Analysis and Proposal," Reference Librarian 15 (Fall 1986): 114.

3. Ibid., 119.

4. Helen Rippier Wheeler, "A Feminist Researcher's Guide to Periodical Indexes, Abstracting Services, Cita on Indexes, and Online Databases," Collection Building 5, no.3 (Fall 1983): 4.

5. Mary Alice Sanguinetti, "Indexing of Feminist Periodicals," Serials Librarian 8, no.4 (Summer 1984): 21.

6. Ibid., 25.

7. Suzanne Hildenbrand, "End User Satisfaction with Computerized Bibliographic Searches in Women's Studies: Preliminary Report of an Investigation," in National Online Meeting Proceedings 1985 (Medford, N.J.: Learned Information, 1985), 215-19.

8. Suzanne Hildenbrand, "Women's Studies Online: Promoting Visibility," RQ 26, no.1 (Fall 1986): 70.

9. Ibid., 72 . 


\section{APPENDIX A}

RECOMMENDATIONS OF TITLES FOR INDEXES AND ABSTRACTS TO ADD

\begin{tabular}{l} 
Index title \\
\hline Alternative Press Index
\end{tabular}

American Humanities Index

Book Review Index

Current Index to Journals in Education (CIJE)

Communication Abstracts

\section{Expanded Academic Index}

General Periodicals (Academic version)

\section{Historical Abstracts}

Humanities Index

Index Medicus

Index to Black Periodicals

Library Literature

Magazine Index
Journals to Add

Bad Attitude

Breaking the Silence

Feminisms

Iris

Law \& Inequality

On the Issues

Women of Power

Trivia

Zora Neale Hurston Forum

Feminisms

Gender and Society

Iris

NWSA Journal

New Directions for Women

Feminist Teacher

Women and Language

Women's Studies in Communication

Feminist Studies

Women's Studies in Communication

Women's Studies International Forum

Frontiers

Mothering

New Directions for Women

Tradeswoman

Women's Sports and Fitness

Hecate

Frontiers

Genders

Heresies

Iris

Journal of Women and Religion

Woman of Power

Women and Performance

Women's Studies in Communication

Health Care for Women International

Zora Neale Hurston Forum

Feminist Bookstore News

Feminist Collections

Lambda Rising Book Report

WLW Journal

Mothering

Women's Sports and Fitness 
APPENDIX A (continued)

\begin{tabular}{|c|c|}
\hline Index title & Journals to Add \\
\hline MLA Bibliography & $\begin{array}{l}\text { Belles Lettres } \\
\text { Hecate } \\
\text { Iris (selectively) } \\
\text { Trivia } \\
\text { IWomen and Language (more fully) } \\
\text { Women and Performance } \\
\text { Zora Neale Hurston Forum }\end{array}$ \\
\hline Philosopher's Index & Journal of Feminist Studies in Religion \\
\hline Reader's Guide & $\begin{array}{l}\text { Mothering } \\
\text { New Directions for Women } \\
\text { Tradeswoman } \\
\text { Women's Sports and Fitness }\end{array}$ \\
\hline Sage Family Studies Abstracts & Health Care for Women International \\
\hline Social Sciences Citation Index & $\begin{array}{l}\text { Gender and Society } \\
\text { Women and Politics }\end{array}$ \\
\hline Social Sciences Index & $\begin{array}{l}\text { Atlantis } \\
\text { Gender and Society } \\
\text { Iris } \\
\text { Law and Inequality } \\
\text { Manushi } \\
\text { Mineroa } \\
\text { Women and Politics }\end{array}$ \\
\hline Sociological Abstracts & $\begin{array}{l}\text { Ahfad Journal } \\
\text { Manushi } \\
\text { Reproductive and Genetic Engineering }\end{array}$ \\
\hline Sport Index & Women's Sports and Fitness \\
\hline Studies on Women Abstracts & $\begin{array}{l}\text { Australian Feminist Studies (more fully) } \\
\text { Feminist Review (more fully) } \\
\text { Manushi } \\
\text { Spare Rib } \\
\text { Studies in Sexual Politics } \\
\text { Trivia (more fully) }\end{array}$ \\
\hline Women Studies Abstracts & $\begin{array}{l}\text { Ahfad Journal } \\
\text { Feminist Review } \\
\text { Harvard Women's Law Journal } \\
\text { Law and Inequality } \\
\text { Lesbian Ethics } \\
\text { Trivia } \\
\text { Trouble and Strife } \\
\text { Women and Performance }\end{array}$ \\
\hline Women Studies Index & $\begin{array}{l}\text { Anima } \\
\text { Bad Attitude } \\
\text { Creative Woman } \\
\text { Daughters of Sarah } \\
\text { Lesbian Contradiction } \\
\text { Sinister Wisdom } \\
\text { Sojourner } \\
\text { Tradeswoman } \\
\text { Visibilities }\end{array}$ \\
\hline
\end{tabular}




\section{Available Now From ACRL}

Association Or

COLLEGE

\& RESEARCH

LIBRARIES

Learning to Teach: Workshops on Instruction

A practical guide for bibliographic instruction practitioners and program coordinators, this book is a useful and usable training manual. Nine workshops cover the basics with clear, concise discussions of classroom techniques, new technologies, and instruction in a multicultural environment. This collection of workshops is designed to develop fundamental skills and address critical issues in bibliographic instruction.

Learning to Teach:

Workshops on Instruction

$\$ 24.99$ (\$21.99 ACRL members)

86p. ISBN 0-8389-7627-1

Order Department

ALA Publishing Services

50 East Huron Street

Chicago, IL 60611-2795
Or call toll-free

1-800-545-2433

FAX: 312-944-2641
Association Of

COLLEGE

\& RESEARCH

LIBRARIES

Association Of

COLLEGE

\& RESEARCH

LIBRARIES

Association Of

COLLEGE

\& RESEARCH

LIBRARIES

Association Of

COLLEGE

\& RESEARCH

LIBRARIES

Association Of

C O L LE G E

\& RESEARCH

LIBRARIES

A DIVISION OF THE

AMERICAN IIBRARY ASSOCIATION 